\title{
The Temporal and Spatial Distribution of Catlinite and Redstone Pipes on Caddo Sites
}

Timothy K. Perttula

Heritage Research Center, Stephen F. Austin State University

Follow this and additional works at: https://scholarworks.sfasu.edu/ita

Part of the American Material Culture Commons, Archaeological Anthropology Commons, Environmental Studies Commons, Other American Studies Commons, Other Arts and Humanities Commons, Other History of Art, Architecture, and Archaeology Commons, and the United States History Commons

Tell us how this article helped you.

This Article is brought to you for free and open access by the Center for Regional Heritage Research at SFA ScholarWorks. It has been accepted for inclusion in Index of Texas Archaeology: Open Access Gray Literature from the Lone Star State by an authorized editor of SFA ScholarWorks. For more information, please contact cdsscholarworks@sfasu.edu. 
The Temporal and Spatial Distribution of Catlinite and Redstone Pipes on Caddo Sites

Creative Commons License

(c) (1) ()

This work is licensed under a Creative Commons Attribution-NonCommercial 4.0 International License 


\title{
The Temporal and Spatial Distribution of Catlinite and Redstone Pipes on Caddo Sites
}

\author{
Timothy K. Perttula
}

\section{INTRODUCTION}

Catlinite and redstone pipes are widely distributed on post-A.D 1450 native American sites across eastern North America, including the Caddo area of the far Southeast (Figure 1). As Rodning (2014:425) indicates, however, catlinite pipes are much more widespread from the late seventeenth century to the early eighteenth century, where the smoking of catlinite pipes is associated with calumet ceremonialism, and the spread of calumet ceremonialism associated with the "spread of European colonists and colonialism."

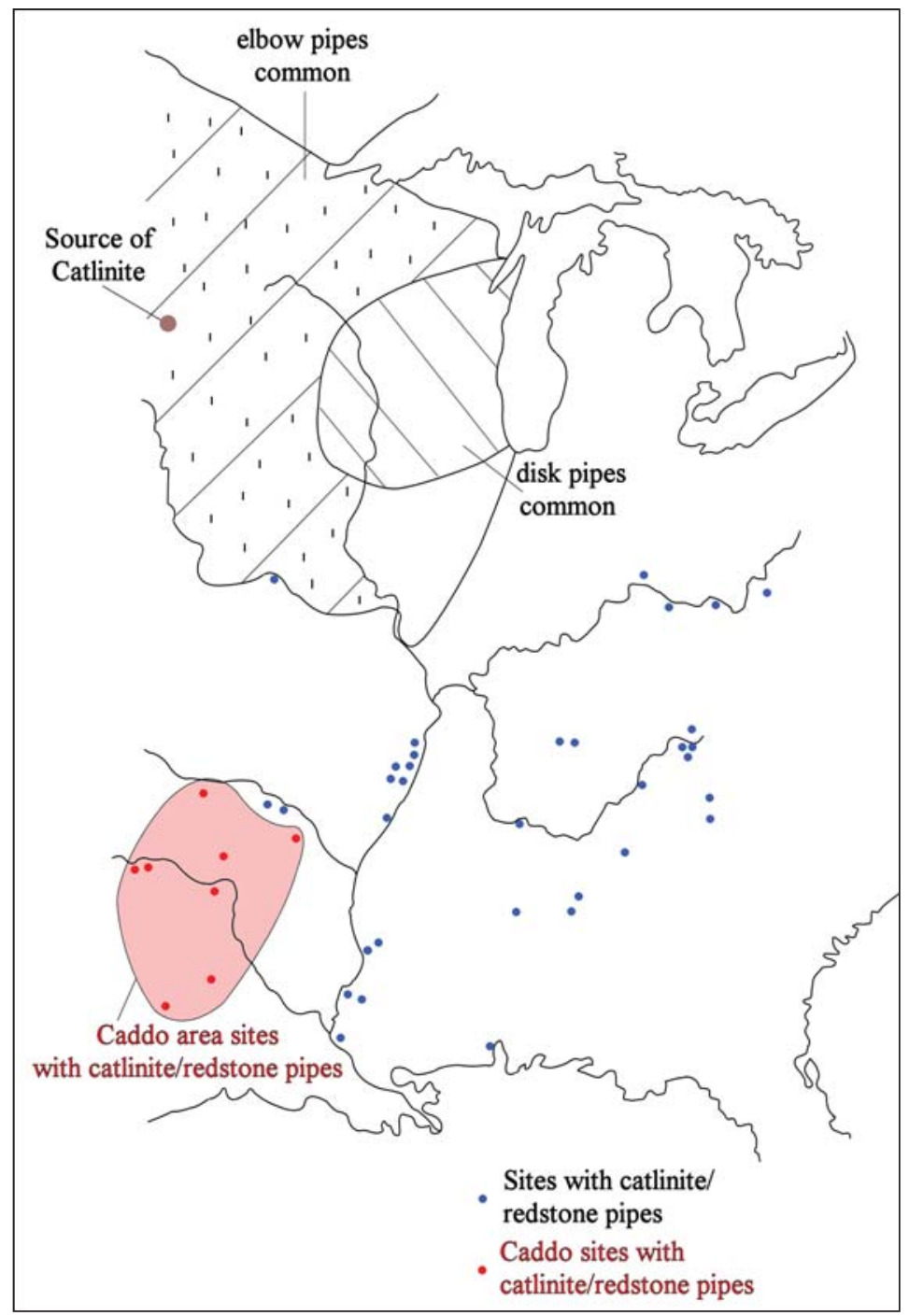

Figure 1. The distribution of sites with catlinite/redstone pipes in eastern North America (after Rodning 2014:Figure 1). 
In this article, I discuss the temporal and spatial distribution of catlinite and redstone pipes on Caddo sites across the northern and southern Caddo areas. These pipes occur in both pre- and post-European contexts in Caddo sites, and take several forms (disk and elbow pipes), but their widest distribution is on sites that date from ca. A.D. 1690-1780 on Caddo sites in East Texas.

Catlinite and redstone pipes are made from argillite found in sources in the Great Plains and the upper Midwest, most notably at Pipestone National Monument in southwestern Minnesota (see Figure 1). According to Rodning (2014:426), the French "colonists are known to have imported argillite and perhaps catlinite from the Midwest or Plains... for the purpose of making calumet pipes to give as gifts to native American groups with whom the French sought alliances."

\section{CALUMET CEREMONIALISM}

The spread of calumet ceremonialism among Native American groups living in the Southeast is apparently related "to the power of associated ritual practices designed to create and to restore balance in the unpredictable and rapidly changing new world of the colonial Southeast" (Rodning 2014:431; see also Brown 2006:404-405). Consequently, the role of calumets in promoting stability and balance, especially in matters of conflict and diplomacy, was of considerable import during the early years of sustained European contact and colonial encounters with Native American groups in the Southeast, including the Caddo peoples. Accordingly, in large part, the catlinite and redstone pipes found on Caddo sites likely constitute evidence that the Caddo peoples, at least those that lived in the late 17th-early 18th century in East Texas, participated in calumet ceremonialism (e.g., Rodning 2014) during a time of early European colonialism in the Caddo area.

Henri Joutel witnessed a calumet ceremony in 1687 among the Cahinnio Caddo, who lived on the Ouachita River in southwestern Arkansas (Foster 1998:254-255):

In the evening, we attended a ceremony that we had not seen before. A group of elders followed by a few young men and some women came as a group singing at the top of their voices near our hut. The first one carried a calumet [or pipe] decorated with various feathers. Having sung for some time before our hut, they entered the hut and continued their songs for about a quarter of an hour.

The next morning, the Cahinnio elders wrapped the calumet in a deer skin sack with "two forked sticks and a crosspiece of red wood," and then they offered the calumet to the French Abbe who was accompanying Joutel. When they did, they told the French that with the calumet, the French "could go to all the tribes who were their allies with this token of piece and that we would be well received everywhere" (Foster 1998:255).

The calumet was not mentioned by Joutel's party when they came through East Texas in 1687 (Foster 1998:255, fn8). Later journeys to East Texas Caddo communities in 1716 and 1718 by Spanish soldiers and missionaries mention the performance of the calumet. Captain Diego Ramon wrote in the diary of his expedition that the calumet pipe "was adorned with many white feathers as a sign of peace among them" (Espinosa 1927:152).

\section{CADDO SITES WITH CATLINITE AND REDSTONE PIPES}

If post-A.D. 900 archaeological sites in the Arkansas River basin of eastern Oklahoma are considered to have been occupied by Caddo peoples, there are currently nine sites in the northern and southern Caddo areas (see Perttula 2012:Figure 1-2) that are known to have catlinite/redstone pipes and pipe fragments. ${ }^{1}$ This includes the Spiro site in eastern Oklahoma, three sites in southwestern Arkansas, and five sites in East Texas (see Figure 1). Only the temporal context of the East Texas Caddo sites with catlinite pipes is known 
with any reliability, namely from ca. A.D. 1690-1780. In general in eastern North America, catlinite/redstone elbow pipes are found on sites only after ca. A.D. 1690, while disk pipes are prevalent on sites dating from ca. A.D. 1450-1650 (see Brown 2006:387-389, 391-401).

\section{Spiro, Eastern Arkansas}

Hamilton (1952:Plate 22a-b) illustrates two catlinite pipes from the Craig mound at the Spiro site. One is a serrated disk pipe and the other is a elbow pipe with a canine head carved at the butt end of the pipe and a carved serpent or snake design on the sides of the pipe; "the figure of a rattlesnake is engraved on the bottom" (Hamilton 1952:39). Hamilton (1952:39) indicates that three disk pipes and six elbow pipes in total may have been found in the southern lobe of the Craig mound, but considers them later intrusive and more recent additions (i.e., postdating A.D. 1450, cf. Brown 1996) to the contents of the mound. Ian Brown (2006:191 and fn133) speculates that it is also "possible that dealers may have attributed these pipes to Spiro to inflate their value, a common practice of the time."

\section{Hughes (3SA11)}

Brown (2006:388) and Jolly (1973:8) both notes that a redstone disk pipe has been found at the Hughes site, but "whose date range is not known" (Brown 2006:388). West (1934:215) indicates the pipe was "reported as having been taken from the base of the Hughes Mound," likely during a 1932 digging investigation by collectors. Although the temporal age of the pipe may not be known, the recent investigations by Trubitt (2012:310) at the site suggest that the main Caddo occupation there, and thus the likely age of the pipe, took place from the late A.D. 1400s to ca. A.D. 1600.

\section{Steele Place, Sevier County, Arkansas}

A redstone disk pipe has been documented from the Steele Place, an unrecorded site, in Sevier County, in southwestern Arkansas (Brown 2006:388; Jolly 1973:8). The age of the pipe is not known.

\section{HS71}

Ann Early indicated that a "small catlinite elbow pipe was reportedly found near the Hedges Site in Hot Spring County. It was in the hands of a collector and I think I got a photo of it back ca. 1976 or so" (August 20, 2014 personal communication). Further information from Early (August 21, 2014 personal communication) indicates that the pipe came from a "low mound in the Ouachita River valley WSW of Malvern," at site 3HS71. The other artifacts identified as coming from the site are probably late 17th century in age, and they include a Hodges Engraved bottle with a spool neck, a Keno Trailed shell-tempered jar, a Foster Trailed-Incised jar, and a Carson Red on Buff bottle. Such bottles date to the late 17th century in Arkansas River lowland sites (Brown 1998:50).

The catlinite pipe itself from 3HS71 is a simple L-shaped form (see Brown 2006:Figure 7d). It has a long stem, and a short, wide bowl, with no embellishments or handles.

\section{Sanders (41LR2)}

A small piece of the rim of a catlinite elbow pipe bowl (7.3 mm in thickness) is in the R. King Harris collection in the National Museum of Natural History at the Smithsonian Institution from the Sanders site; 
it likely was collected from the surface of the site. It has a single deep horizontal line engraved under the bowl lip. The catlinite pipe fragment from the Sanders site is likely associated with the extensive ca. A.D. 1690-1730 Womack phase occupation of the Sanders site (Perttula et al. 2015), and is the westernmost Caddo site with catlinite pipes (Figure 2).

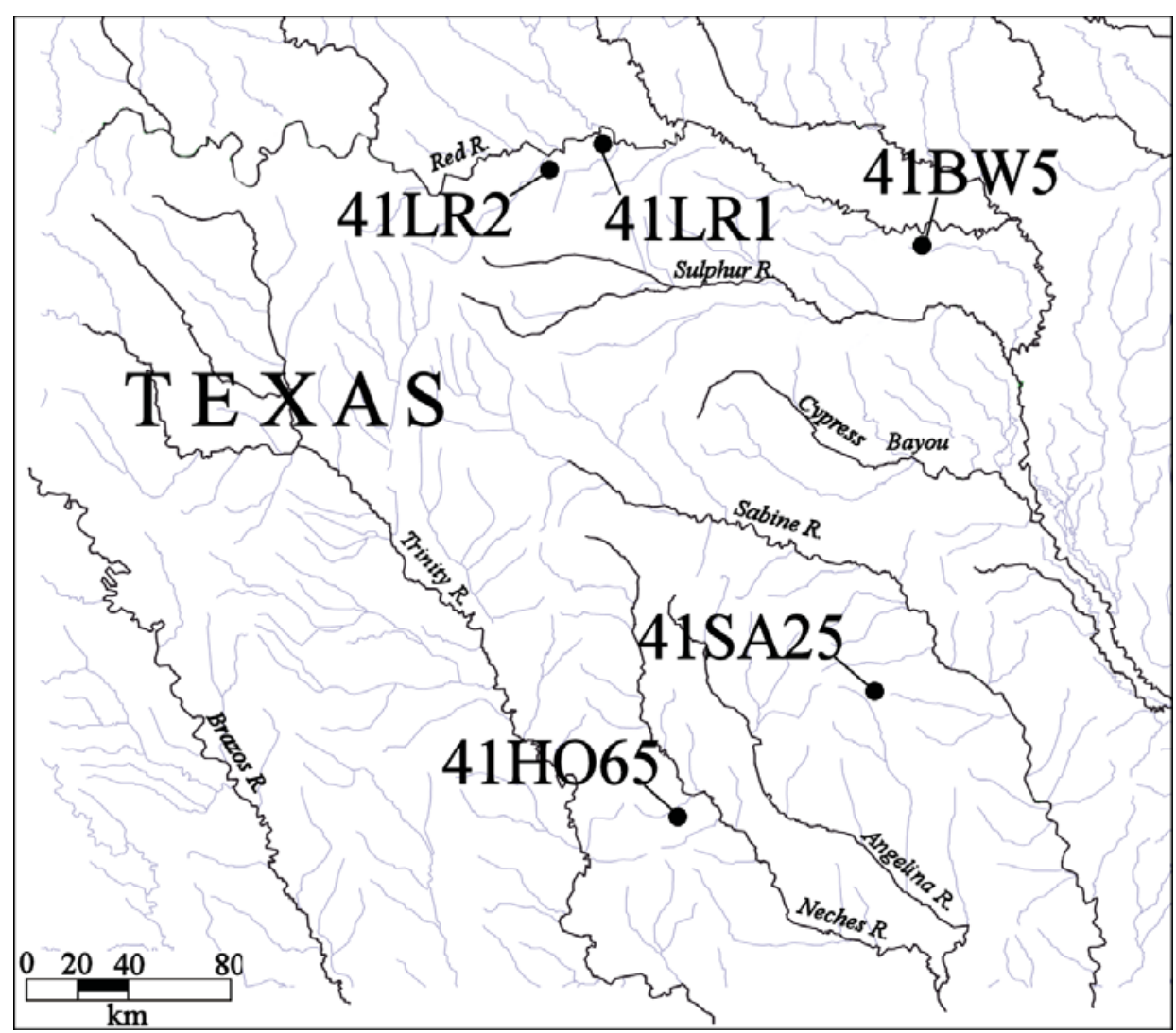

Figure 2. East Texas Caddo sites with catlinite/redstone pipes.

\section{Womack (41LR1)}

Two different catlinite elbow pipes have been found in the ca. A.D. 1700-1730 Womack phase occupation at the Womack site. Pearce and Jackson (1931:3) reported that a catlinite pipe fragment had been found on the surface of the site. Todd (2010:Figure 1) illustrates the pipe (Figure 3), which is a T-shaped form with a notched prow or handle (cf. Brown 2006:393). There is a single hole or perforation on the prow that may have "held feathers or other ornaments" (Brown 2006:393). This pipe is no longer in the collections at TARL (Perttula 2015).

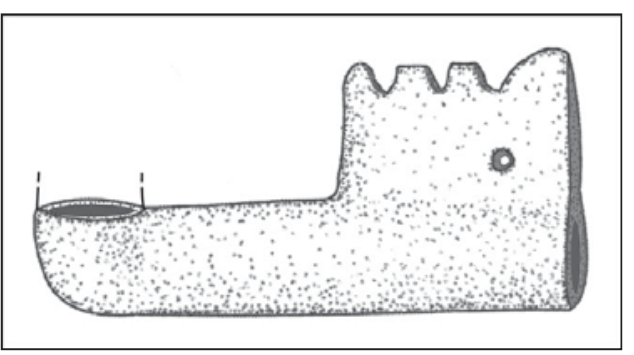

Figure 3. T-shaped catlinite pipe from the surface of the Womack site. 
The second catlinite pipe fragment is an elbow pipe bowl, probably an L-shaped elbow pipe (cf. Brown 2006:393), recovered by Harris et al. (1965:Figure 3k; see also Todd 2010:Figure 2). The pipe bowl is 51 $\mathrm{mm}$ in length and has an orifice diameter of $26 \mathrm{~mm}$ (Todd 2010:139).

\section{Roseborough Lake (41BW5)}

A single catlinite pipe stem sherd from an elbow pipe was found in Feature 3 at the Roseborough Lake site (Miroir et al. 1973:123 and Figure 6f). Feature 3 is an occupational feature in the ca. A.D. 1719-1778 Nasoni Caddo component at the site (Miroir et al. 1973:Figure 2).

\section{HO65, San Pedro de los Nabedaches}

This site is one of a number of post-A.D. 1690 Nabedache Caddo archaeological sites known on San Pedro Creek in the Neches River basin in East Texas. The Spanish referred to this area, in which they established the first mission among the Hasinai Caddo groups, as San Pedro de los Nabedaches, in 1690 (Bolton 1987:45).

The catlinite pipe from $41 \mathrm{HO} 65$ is a T-shaped elbow pipe with a square stem and a prominent notched prow or handle (Figure 4a-b; see also Perttula 2004:Figure 9a-b). There is a $2.5 \mathrm{~mm}$ drilled hole near one end of the prow, similar to one of the elbow pipes from the Womack site (see Figure 3), and meant to hold feathers or other ornaments. There are two broad incised lines etched into the stem, extending from the stem opening to near where the cylindrical bowl was attached to the stem. Spectroscopy of the 41HO65 pipe performed by Thomas E. Emerson and Randall E. Hughes indicated that the " $41 \mathrm{HO} 65$ specimen is made from catlinite from the pipestone quarries centered at the Pipestone National Monument" (Perttula 2004:98) in southwestern Minnesota (see Figure 1).
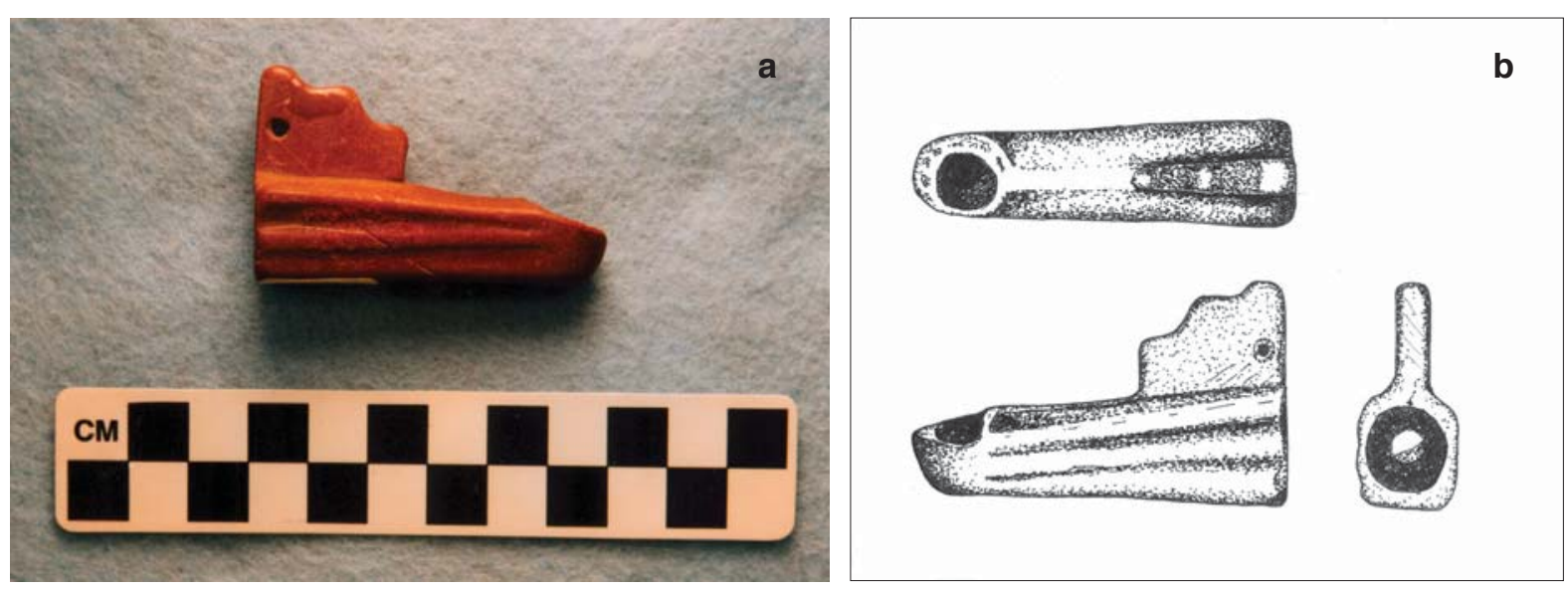

Figure 4. Catlinite T-shaped elbow pipe from 41HO65: a, side view; b, drawing by Nancy G. Reese of the catlinite pipe from several perspectives. Reproduced with the courtesy of the Texas Archeological Society.

\section{Mission Dolores de los Ais (41SA25)}

Corbin et al. (1990:123 and Figure 54j) recovered a red pipestone sherd from an L-shaped elbow pipe during the excavations of Mission Dolores de los Ais in East Texas. This mission was occupied between 1717-1773. 


\section{SUMMARY AND CONCLUSIONS}

Catlinite and redstone pipes have been recovered from nine archaeological sites in the Caddo area, including the Spiro site in the Arkansas River basin in eastern Oklahoma, three Caddo sites in southwestern Arkansas, and five sites in East Texas. Disk pipes (see Brown 2006:Figure 2) have been found only on the eastern Oklahoma and southwestern Arkansas Caddo sites, likely from ca. A.D. 1450-1650 contexts, where they represent items of exchange from networks of exchange and interaction that existed before European contact. The catlinite and redstone elbow pipe form (see Brown 2006:Figures 6 and 7) is present at the Spiro site, one site in Southwest Arkansas, and all five of the East Texas Caddo sites. The age of the Spiro catlinite elbow pipes is not known, but the catlinite pipes on the East Texas Caddo sites all date from the late seventeenth century until as late as ca. A.D. 1780 contexts, while the ceramic vessels from 3HS71 likely date the catlinite pipe there to the late 17th century. These pipes constitute archaeological evidence of the participation of different Caddo groups in calumet ceremonialism, and are found at Caddo villages on the Red River and East Texas, as well as in archaeological deposits associated with the Spanish mission first established for the Ais in 1717. The places where the catlinite and redstone pipes and pipe sherds have been found likely represent important places of diplomacy and ritual practice as well as gateways to the East Texas Caddo world.

\section{END NOTES}

1. According to Pete Gregory (August 18, 2014 personal communication), there is a small redstone pipe, possibly catlinite, "with lead inlay in the Clint Pine private collection that he picked up on the edge of campus along Hwy. 6 at the edge of Young's Bayou [in Natchitoches, Louisiana]. We did a lot of shovel testing around the bridge right of way, found not a single European or historic Indian sherd!"

\section{ACKNOWLEDGMENTS}

I appreciate the information provided by George Avery, Ann Early, Mary Beth Trubitt, Pete Gregory, and Scott Hammerstedt about Caddo sites with catlinite/redstone pipes. I also thank Lance Trask for preparing the figures in this article, except for Figure 4a, which was provided by Bo Nelson, and Figure 4b, which was provided by Nancy G. Reese.

\section{REFERENCES CITED}

Bolton, H. E.

1987 The Hasinais: Southern Caddoans as seen by the earliest Europeans. University of Oklahoma Press, Norman.

Brown, I. W.

1998 Decorated Pottery of the Lower Mississippi Valley: A Sorting Manual. Mississippi Archaeological Association and Mississippi Department of Archives and History, Jackson.

2006 The Calumet Ceremony in the Southeast as Observed Archaeologically. In Powhatan's Mantle: Indians in the Colonial Southeast, edited by G. A. Waselkov, P. H. Wood, and T. Hatley, pp. 371-419. Second Edition. University of Nebraska Press, Lincoln.

Brown, J. A.

1996 The Spiro Ceremonial Center. The Archaeology of Arkansas Valley Caddoan Culture in Eastern Oklahoma. 2 Vols. Memoir No. 29. Museum of Anthropology, University of Michigan, Ann Arbor. 
Corbin, J. E., H. A. Brown, M. G. Canavan, and S. Toups

1990 Mission Dolores de los Ais (41SA25): San Augustine County, Texas, Archeological Investigations. Stephen F. Austin State University, Nacogdoches

Espinosa, Fr. I. F. de

1927 Descriptions of the Tejas or Asinai Indians, 1691-1722. Translated by M. A. Hatcher. Southwestern Historical Quarterly 31:150-180.

Foster, W. C. (editor)

1998 The La Salle Expedition to Texas: The Journal of Henri Joutel, 1684-1687. Texas State Historical Association, Austin.

Hamilton, H. W.

1952 The Spiro Mound. The Missouri Archaeologist 14:1-276.

Harris, R. K., I. M. Harris, J. C. Blaine, and J. Blaine

1965 A Preliminary Archeological and Documentary Study of the Womack Site, Lamar County, Texas. Bulletin of the Texas Archeological Society 36:287-365.

Jolly, F., III

1973 A Catlinite Disk Pipe and Associated Vessels from lowland Eastern Arkansas. The Arkansas Archeologist 14(1):1-12.

Miroir, M. P., R. K. Harris, J. C. Blaine, and J. McVay

1973 Benard de la Harpe and the Nassonite Post. Bulletin of the Texas Archeological Society 44:113-167.

Pearce, J. E. and A. T. Jackson

1931 Field Notes: Excavation on the H. E. Womack Farm, Lamar County, Texas, August 29, 1931 to September 4, 1931. MS on file, Texas Archeological Research Laboratory, The University of Texas at Austin.

Perttula, T. K.

2004 (with contributions by T. E. Emerson and R. E. Hughes) 41 HO64/41HO65, Late $17^{\text {th }}$ to Early $18^{\text {th }}$ Century Caddo Sites on San Pedro Creek in Houston County, Texas. Bulletin of the Texas Archeological Society 75:85-103.

2015 The Womack Site (41LR1), an Ancestral Caddo Settlement on the Red River in Lamar County, Texas. Journal of Northeast Texas Archaeology 52, in press.

Perttula, T. K., B. Nelson, M. Walters, and R. Z. Selden Jr.

2015 The Sanders Site (41LR2): A Middle to Historic Caddo Settlement and Mound Center on the Red River in Lamar County, Texas. Journal of Northeast Texas Archaeology 50:1-87.

Rodning, C. B.

2014 Cherokee Towns and Calumet Ceremonialism in Eastern North America. American Antiquity 79(3):425443.

Todd, J.

2010 Two Catlinite Pipe Fragments from the Womack Site, Lamar County, Texas. Caddo Archeology Journal 20:139-142.

Trubitt, M. B.

2012 Caddo in the Saline River Valley of Arkansas: The Borderlands Project and the Hughes Site. In The Archaeology of the Caddo, edited by T. K. Perttula and C. P. Walker, pp. 288-312. University of Nebraska Press, Lincoln.

West, G. A.

1934 Tobacco, Pipes and Smoking Customs of the American Indians. Bulletin of the Public Museum of the City of Milwaukee Volume XVII, Part I. 